\title{
Dynamics in population heterogeneity during batch and continuous fermentation of Saccharomyces cerevisiae
}

Heins, Anna-Lena; Lencastre Fernandes, Rita; Lundin, L.; Carlquist, M.; Sörensen, S.; Gernaey, Krist; Eliasson Lantz, Anna

Published in:

New Biotechnology

Link to article, DOI:

10.1016/j.nbt.2012.08.561

Publication date:

2012

Document Version

Publisher's PDF, also known as Version of record

Link back to DTU Orbit

Citation (APA):

Heins, A-L., Lencastre Fernandes, R., Lundin, L., Carlquist, M., Sörensen, S., Gernaey, K., \& Eliasson Lantz, A. (2012). Dynamics in population heterogeneity during batch and continuous fermentation of Saccharomyces cerevisiae. New Biotechnology, 29S, S199-S200. https://doi.org/10.1016/j.nbt.2012.08.561

\section{General rights}

Copyright and moral rights for the publications made accessible in the public portal are retained by the authors and/or other copyright owners and it is a condition of accessing publications that users recognise and abide by the legal requirements associated with these rights.

- Users may download and print one copy of any publication from the public portal for the purpose of private study or research.

- You may not further distribute the material or use it for any profit-making activity or commercial gain

- You may freely distribute the URL identifying the publication in the public portal 
The chiral results depict a distribution of positive and negative enantiomers produced by Lavandin super, where Linalool is mainly negative enantiomer, Camphor is just negative enantiomer and Borneol and Terpineol-4-ol are formed by their positive enantiomer.

This work has been partially supported by grants from several Spanish organizations. Projects BIO2009-12956 (MICINN, Madrid) and 08856/PI/08 (Fundación Seneca, CARM, Murcia). AC has a fellowship from Esencias Martinez Lozano S.A. (Murcia).

http://dx.doi.org/10.1016/j.nbt.2012.08.558

\section{Poster 5.0.119}

Improving the thermostability of D-tagatose 3-epimerase for the production of the rare sugar $D$-psicose

Andreas Bosshart*, Nina Wagner, Matthias Bechtold, Sven Panke

ETH Zürich, Department of Biosystems Science and Engineering (DBSSE) Mattenstrasse 264058 Basel, Switzerland

Uncommon monosaccharides (rare sugars) such as D-psicose are of considerable interest as chiral building blocks, low-calorie sweeteners or active pharmaceutical ingredients. A large set of rare sugars can be produced directly from cheap substrates such as D-glucose, L-sorbose or D-galactose via established enzymatically catalyzed isomerization and epimerization reactions.

D-Tagatose 3-epimerases (DTEs) constitute the central enzymes in this approach as they enable the C3-epimerization of all ketohexoses. However, the wild-type DTE from P. cichorii (PcDTE) showed insufficient thermostability which we addressed with a semi-rational protein engineering approach aiming in particular at reinforcing the subunit interaction. The crystal structure of PcDTE shows that the enzyme forms a homodimer [Yoshida et al., JMB, 2007] and revealed 41 residues as part of the interface. Highly conserved residues identified by sequence alignment were excluded, the remaining 34 residues were targeted each by site-saturation mutagenesis of single residues.

For 9 sites beneficial single substitutions with significantly improved thermostability were obtained, which manifested in an increase of $T_{50}{ }^{20}$ (temperature at which $50 \%$ activity loss is observed after $20 \mathrm{~min}$ ) from $T_{50}{ }^{20}=65.6^{\circ} \mathrm{C}$ (wt) up to the range of $67-78.1^{\circ} \mathrm{C}$. All 9 positions were combined by the reduced combinatorial ISM approach described by Reetz [Reetz et al., Nat. Protoc., 2007] with the final variant exhibiting a drastically improved $T_{50}{ }^{20}$ of $87^{\circ} \mathrm{C}$, a $\Delta T_{50}{ }^{20}$ of $21.4^{\circ} \mathrm{C}$ compared to wild-type.

We could demonstrate that targeting interface residues by the powerful ISM method delivers a greatly stabilized multimeric enzyme and therefore complements the available set of protein stabilization methods.

http://dx.doi.org/10.1016/j.nbt.2012.08.559

\section{Poster 5.0.120}

Biodegradation of lipophilic compounds in emulsified systems

\section{Anna Trusek-Holownia*, Andrzej Noworyta}

Wroclaw University of Technology, Department of Chemistry, Norwida 4/6, 50-373 Wroclaw, Poland

Despite the attractiveness of biological methods in removing harmful substances coming from the industrial waste streams, a serious limitation for their use is very low solubility in water of some organic compounds. This issue relates to e.g. oil pollutions commonly occurring in the environment.

The purpose of this study was biodegradation of alkanes with a strain of Acinetobacter lwoffii in conventional reactors with emulsified substrate phase and in the system enriched by membrane module.

Since the process carried out in emulsified systems not goes quickly, and the substrate is not fully converted, a system comprising an ultrafiltration membrane module was proposed. Increase the efficiency of the biodegradation process was expected due to:

1. biomass concentration;

2. intensive phase emulsification by turbulent flow of the feed;

3. lack of the effect called "ring" made up of cells located at the interface, which was the reason for slowing the biodegradation process;

4. full substrate conversion with respect to the permeate stream leaving the installation, when the applied membrane fully rejects the substrate particles.

Using a variable value relationships permeate flux to dosing stream, in a membrane reactor achieved varying degrees of intensification of the biodegradation of alkanes; e.g. at the 3.3-fold increasing in biomass concentration, 13.2 times lower concentration of alkanes in the stream leaving the installation was obtained. This value confirms a significant increase in conversion of the lipophilic substrates obtained in membrane bioreactor.

Polish Ministry of Science and Higher Education supported this work in a framework of a project no. 310040/Z0311/W3.

http://dx.doi.org/10.1016/j.nbt.2012.08.560

\section{Poster 5.0.121}

Dynamics in population heterogeneity during batch and continuous fermentation of Saccharomyces cerevisiae

A.L. Heins ${ }^{1, *}$, R. Lencastre Fernandes ${ }^{2}$, L. Lundin ${ }^{3}$, M. Carlquist ${ }^{4}$, S. Sörensen ${ }^{3}$, V.K. Gernaey ${ }^{2}$, A. Eliasson Lantz ${ }^{1}$

${ }^{1}$ Center for Microbial Biotechnology, Technical University of Denmark, Denmark

${ }^{2}$ Department of Chemical and Biochemical Engineering, Technical University of Denmark, Kgs. Lyngby, Denmark

${ }^{3}$ Department of Biology, University of Copenhagen, Copenhagen, Denmark

${ }^{4}$ Department of Chemistry, Lund University, Lund, Sweden

Traditionally, microbial populations in optimization studies of fermentation processes have been considered homogeneous. However, research has shown that a typical microbial population in 
fermentation is heterogeneous. There are indications that this heterogeneity may be both beneficial (facilitates quick adaptation to new conditions) and harmful (reduces yields and productivities) $[1,2]$.

Typically, gradients of e.g. dissolved oxygen, substrates, and $\mathrm{pH}$ are observed in industrial scale fermentation processes. Consequently, microbial cells circulating throughout a bioreactor experience rapid environmental changes, which might pose stress on the cells, affect their metabolism and consequently influence the level of heterogeneity of the population.

To gain a deeper understanding of population heterogeneity and the triggering phenomena, a Saccharomyces cerevisiae growth reporter strain based on the expression of green fluorescent protein (GFP) was constructed which enable to perform single cell analysis, and thereby provides a tool to map population heterogeneity.

A factorial design experiment followed by multivariate data analysis demonstrated a highly dynamic behavior with regard to subpopulation distribution during different growth stages. To further simulate which effect gradients have on population heterogeneity, glucose and ethanol perturbations during continuous cultivation were performed. Physiological changes were analyzed on single cell level by using flow cytometry followed by cell sorting of different subpopulations. Furthermore the expression of the reporter gene was examined by qPCR.

It could be demonstrated that pulses had a clear influence on population distribution. In conclusion, we now have a tool to study the effect environmental gradients have on population heterogeneity.

\section{References}

1. Bylund F, et al. Substrate gradient formation in the large-scale bioreactor lowers cell yield and increases by-product formation. Bioprocess Biosyst Eng 1998;18:171-80.

2. Enfors SO, et al. Physiological responses to mixing in large scale bioreactors. J Biotechnol 2001;85:175-85.

http://dx.doi.org/10.1016/j.nbt.2012.08.561

\section{Poster 5.0.122}

Influence of microcarrier concentration and ratio cells/microcarrier on SKHep cell growth and protein production

C.M.R. Andrade ${ }^{1}$, M.A. Aguiar ${ }^{1}$, R.J. Andrade ${ }^{1}$, D.T. Covas $^{2}$, E.F.P. Augusto $^{1, *}$

${ }^{1}$ Laboratory of Industrial Biotechnology, IPT - Instituto de Pesquisas Tecnológicas, Av. Prof. Almeida Prado, 532, 05508-901, S. Paulo, SP, Brazil

${ }^{2}$ Fundação Hemocentro de Ribeirão Preto - Rua Tenente Catão Roxo, 2501 - Monte Alegre - 14021-140, Ribeirão Preto, SP, Brazil

The coagulation factor FVIII is recognized as the largest most complex and most challenging recombinant protein therapeutic manufactured. Due to its high degradability, the protein is preferably produced in perfusion mode. However, to reach this complex kind of operation, a deep knowledge of the cell line metabolism is a must. In this work, a SKHep cell line stably transfected to produce coagulation factor VIII (rFVIII) was grown on Cytodex 3 (GE) microcarriers in Spinner flasks. This work aimed to evaluate the influence of the microcarrier concentration (3-15 g/L) and the ratio cells/microcarrier (1-8) on cell growth and protein production. It was observed that, when more than 3 cells/micc were added, cell metabolism changed, characterized by decreases of $45 \%$ in $\mu_{X, \operatorname{MAX}}$ and $55 \%$ in $\mathrm{Y}_{\mathrm{X} / \mathrm{GLC}}$, and an increase of 2.5 times in $\mathrm{Y}_{\mathrm{NH} 4 / \mathrm{X}}$ values. Between 1 and 3 cells/micc, there were no changes in cell metabolism, but this last condition showed a rFVIII production per cell $\left(\mathrm{Y}_{\mathrm{rFVIII} / \mathrm{X}}\right)$ 25\% higher than the others. Microcarriers concentration between 3 and $9 \mathrm{~g} / \mathrm{L}$ do not influence cell growth, metabolism or rFVIII production. However, a concentration of $15 \mathrm{~g} / \mathrm{L}$ resulted in no cell growth, probably due to the high collision frequency between beads, which may have increased shear stress.

http://dx.doi.org/10.1016/j.nbt.2012.08.562

\section{Poster 5.0.123}

Xylanase production by Cryptococcus flavescens and Aureobasidium pullulans using steam exploded bagasse

Cristiane Conte Paim de Andrade*, Tatiana Porto dos Santos, Maria Isabel Rodrigues, Francisco Maugeri Filho

University of Campinas (UNICAMP), Brazil

Xylanases are hemicellulose degrading enzymes that have widespread roles in different industrial fields, as production of second generation ethanol, waste treatment, animal feed, nutrition, pulp and paper industries treatment. The production of this kind of enzyme is, usually, done by molds and bacteria, although there are some studies with yeasts, especially those from Cryptococcus genus, or yeast-like microrganisms, as the color variant Aureobasidium pullulans. The aim of this study was to evaluate the xylanase production using pretreated sugar cane bagasse as substrate. Raw bagasse, three different conditions (soft, moderated and high) of steam exploded bagasse and their corresponding soluble fractions were assayed. The media were supplemented with molasse or synthetic compounds, and remotion of inhibitors has also been tested by activated charcoal or biphasic fermentation. A flask with synthetic medium and $1 \%$ beechwood xylan was used as control. The production of extracellular xylanase was carried-out during $96 \mathrm{~h}$ of fermentation in shake flasks and samples were taken every $12 \mathrm{~h}$. The presence of molasses repressed the xylanase expression, as well as the treatment of the soluble fraction with activated charcoal or the biphasic fermentation reduced activity of xylanase. At assayed conditions, the steam soft pre-treated bagasse soluble fraction (added with synthetic compounds) was favorable for xylanase production by Cryptococcus flavescens $(1.68 \mathrm{U} / \mathrm{mL}$ at $36 \mathrm{~h})$, while Aureobasidium pullulans reached higher levels of xylanase expression in moderate treatment $(5.28 \mathrm{U} / \mathrm{mL}$ at $24 \mathrm{~h})$. Further studies, as experimental design, may improve the enzyme induction in selected steam explosion treatments.

Acknowledgments: CNPq, Fapesp.

http://dx.doi.org/10.1016/j.nbt.2012.08.563 